\title{
The Application of Financial Statement Analysis in Strategic Management
}

\author{
Ping Xiao \\ Hunan University of Humanities, Science and Technology, Loudi, Hunan 417000, China. \\ applefly13@126.com
}

\begin{abstract}
The business activities of enterprises is closely related to strategic management, the business will lay a deep imprint in the financial statements of the enterprise, the enterprise strategic management to implement enterprise strategy through the assets of the financial project resources optimized allocation and effective operation, so for the analysis of financial statement analysis is no longer a simple corporate balance sheets, but through the financial statement analysis behind the mining enterprise strategic management. This paper mainly through the analysis of green electric appliances co., LTD. In recent years, the financial statements to dig behind the strategic management, through financial statements analysis showed that green electric appliances co., LTD adopts the strategic management, business and investment and gradually shift from specialization strategy to diversification strategy.
\end{abstract}

Keywords: Strategic management, financial statement analysis, diversification strategy.

\section{Introduction}

There are three main analysis methods for financial statement analysis: ratio analysis, structure analysis and quality analysis. At the same time the three analysis methods can effective analysis enterprise's financial and operating conditions, with the development of economy and the development of accounting theory and practice, the enterprise financial management is no longer the limit analysis of financial situation, more is to through the financial statement analysis of mining enterprise strategic management. This paper analyzes financial statements from the perspective of enterprise strategic management through some financial statement data of Gere Electric Appliances, Inc. Of Huizhou from 2015 to 2017.

\section{Analysis of Financial Statements Through the Strategic Management}

Strategic management is a continuous process, not through the financial statements reflect a year, so this paper selected the green electric appliances of 2015-2017 financial statements about the relevant data analysis, from the financing strategy, investment strategy and strategic management of green electric appliances operation strategy to mining.

\subsection{Analysis of Financing Strategy}

From table 1, 2015-2017 in the balance sheet shows, Gere Electric Appliances, Inc. of Zhuhai currency funds increased year by year, short-term loans increased year by year, but the scale of the short-term borrowing relative to the size of the monetary fund is more little, that money is not by exogenous financing, compared to such a large scale, the monetary fund exogenous financing seem unnecessary. The main reason for the rise of money capital and the relatively large scale is the recovery of the due amount of notes receivable and the sharp increase of green electric's operating income. In the case of sufficient money and capital, green electric still has stable external borrowing year by year, and its financial expenses are negative, mainly to maintain a certain credit relationship with financial institutions. Parent company and consolidated from table 1 shows notes payable, accounts payable project size is larger, embodies the green electric appliances and the payment of the supplier management arrangements, green electric appliances business resources mainly comes from the liabilities of the supplier, explain enterprise financing mainly comes from the financing for 
commercial purposes through management of payment arrangement with upstream enterprises endogenous financing.

Table 1. Balance sheet of the green electric appliance of Zhu Hai. (Unit: RMB/Yuan)

\begin{tabular}{c|c|c|c}
\hline \multirow{2}{*}{ project } & \multicolumn{3}{|c}{ The parent company } \\
\cline { 2 - 4 } & $2015 / 12 / 31$ & $2016 / 12 / 31$ & $2017 / 12 / 31$ \\
\hline Monetary fund & $88,680,099,321.27$ & $94,358,894,092.06$ & $97,829,294,130.39$ \\
\hline Notes receivable & $13,754,447,428.79$ & $28,681,394,851.75$ & $28,046,280,904.73$ \\
\hline Accounts receivable & $3,416,105,149.73$ & $1,029,622,972.59$ & $1,384,793,962.56$ \\
\hline $\begin{array}{c}\text { Long-term equity } \\
\text { investment }\end{array}$ & $6,854,879,074.54$ & $7,713,333,058.50$ & $8,459,424,755.85$ \\
\hline Other receivables & $3,634,956,003.75$ & $848,175,367.89$ & $2,554,031,364.44$ \\
\hline inventory & $8,670,596,377.12$ & $7,847,311,118.65$ & $10,803,398,501.22$ \\
\hline Fixed assets & $3,986,232,943.74$ & $3,482,273,291.47$ & $3,367,990,958.20$ \\
\hline Total assets & $139,843,307,067.51$ & $162,923,876,928.29$ & $180,205,236,502.04$ \\
\hline Short-term borrowing & $2,675,363,200.00$ & $7,136,785,600.00$ & $12,174,152,000.00$ \\
\hline Notes payable & $7,237,386,266.55$ & $10,045,470,518.12$ & $9,123,098,986.97$ \\
\hline Accounts payable & $40,616,067,475.26$ & $41,793,337,033.46$ & $38,206,787,386.72$ \\
\hline $\begin{array}{c}|c| \\
\text { Project }\end{array}$ & \multicolumn{3}{|c}{ consolidated } \\
\cline { 2 - 4 } Monetary fund & $2015 / 12 / 31$ & $2016 / 12 / 31$ & $2017 / 12 / 31$ \\
\hline Notes receivable & $88,819,798,560.53$ & $95,613,130,731.47$ & $99,610,431,730.40$ \\
\hline Accounts receivable & $14,879,805,537.96$ & $29,963,355,478.45$ & $32,256,413,538.14$ \\
\hline Long-term equity & $2,879,212,111.93$ & $2,960,534,651.37$ & $5,814,491,641.18$ \\
\hline investment & $95,459,187.55$ & $103,913,171.51$ & $110,391,368.86$ \\
\hline Other receivables & $254,016,643.00$ & $244,984,154.67$ & $252,825,686.48$ \\
\hline Inventory & $9,473,942,712.51$ & $9,024,905,239.41$ & $16,568,347,179.12$ \\
\hline Fixed assets & $15,431,813,077.20$ & $17,681,655,478.06$ & $17,467,371,455.63$ \\
\hline Total assets & $161,698,016,315.06$ & $182,369,705,049.35$ & $214,967,999,328.38$ \\
\hline Short-term borrowing & $6,276,660,136.03$ & $10,701,081,645.32$ & $18,646,095,044.32$ \\
\hline Notes payable & $7,427,635,753.74$ & $9,127,336,849.68$ & $9,766,929,541.33$ \\
\hline Accounts payable & $24,794,268,372.47$ & $29,541,466,861.10$ & $34,552,886,331.56$ \\
\hline
\end{tabular}

\subsection{Investment Strategy Analysis}

In order to clear the investment strategy of the enterprise, this paper is divided into two types, the investment assets that controlling investment (long-term equity investment and other receivables, etc.) and other investments (trading financial assets and available for sale financial assets, etc.), when the enterprise of a long-term equity investment in the way of controlling investment, controlling investment will form the invested company business assets, enterprise development strategy of foreign expansion meaning more obvious. See from table 1 in the parent company statements, 20152017 of a long-term equity investment increased year by year, the parent company to control foreign investment by the parent company statements of the long-term equity investment and other receivables project performance. When the consolidated gross assets and its parent table is far greater than the difference between the total value of assets of the parent company, controlling investment assets that controlling the expansion effect of the parent company, the parent company through controlling investment (parent company to long-term equity investments and other receivables and merge table of the difference of the long-term equity investment and other receivables) achieved good development, the subsidiaries do business ability and level is high. It is worth noting that the number of controlled investment scale is only a rough estimate, but as a strategic analysis, such treatment can largely reflect the enterprise's foreign investment strategy. In 2017, for example, the parent company leverages the increment of the total assets of a group of subsidiaries about 34.7 billion by about 11 
billion controlled investments, which promotes the leapfrog development of the group's foreign investment.

\subsection{Analysis of Business Strategy}

Despite the comprehensive enterprise strategy management, the result can't directly into assets, but for the assets of enterprises through optimizing configuration can realize enterprise strategy, can through asset portfolio to mining enterprise's strategic management. For example, the scale of fixed assets and inventories directly reflects the business model of enterprises. Enterprise business debt s(including accounts receivable and notes receivable) scale and structure reflects the enterprise's marketing model, the size and structure of enterprise business debt (including accounts payable and notes payable) reflected the enterprise resource acquisition mode. When enterprises strengthen their own business activities, they will often strengthen the construction of fixed assets, inventories and intangible assets, which is manifested as the increase of fixed assets and inventory scale. From shown in table 1, 2015-2017 of fixed assets increases year by year, embodies the green electric appliances is determined to expand their operations in 2016 compared with 2015 in stock inventory were significantly reduced, at the same time, the parent company's operating income increased from 2016 in 110.1 billion to 2017 in 150 billion, green electric appliances operation ability enhancement. It can be seen from the parent company's statement and consolidated statement that the parent company and its subsidiaries are mainly expanding their operations, and the main business development is still the main strategy of green electric appliances.

Enterprise management strategy directly affect the enterprise's operating income, from the merger of green electric appliances in the income statement, compare the operating income in 2017 to that in 2016, operating income increased by about 40 billion, operating income rose in 2015, the main reason of the transformation is successful, that is, from specialization to diversification expansion.

Enterprises to adopt strategic management, the purpose is to promote the competitiveness of the enterprise itself, shown in figure 1, in 2017 green electric current liabilities structure, notes payable, accounts payable, advances from funds account for about $33.5 \%$ of the total current liabilities. Bills payable and accounts receivable squeeze the funds of upstream suppliers, and advance sales squeeze the funds of downstream dealers. From the structure enterprise accounts payable are larger than notes payable, notes receivable is much larger than the size of enterprise receivables, manifested the enterprise in the management of upstream and downstream relationships bargaining power is strong, showed a "two head to eat" competition ability.

Table 2. Current liabilities

All current liabilities of green electric appliances in 2017

\begin{tabular}{c|c|c}
\hline x1 & Notes payable & $9,123,098,986.97$ \\
\hline x2 & Accounts payable & $38,206,787,386.72$ \\
\hline x3 & Other current liabilities & $60,900,715,131.17$ \\
\hline x4 & Short-term borrowing & $12,174,152,000.00$ \\
\hline x5 & Pay payable & $808,745,204.92$ \\
\hline x6 & Payable taxes & $2,848,508,249.51$ \\
\hline x7 & Interest payable & $184,231,020.61$ \\
\hline x8 & Dividends payable & $602,881.87$ \\
\hline x9 & Other accounts payable & $598,324,960.97$ \\
\hline
\end{tabular}




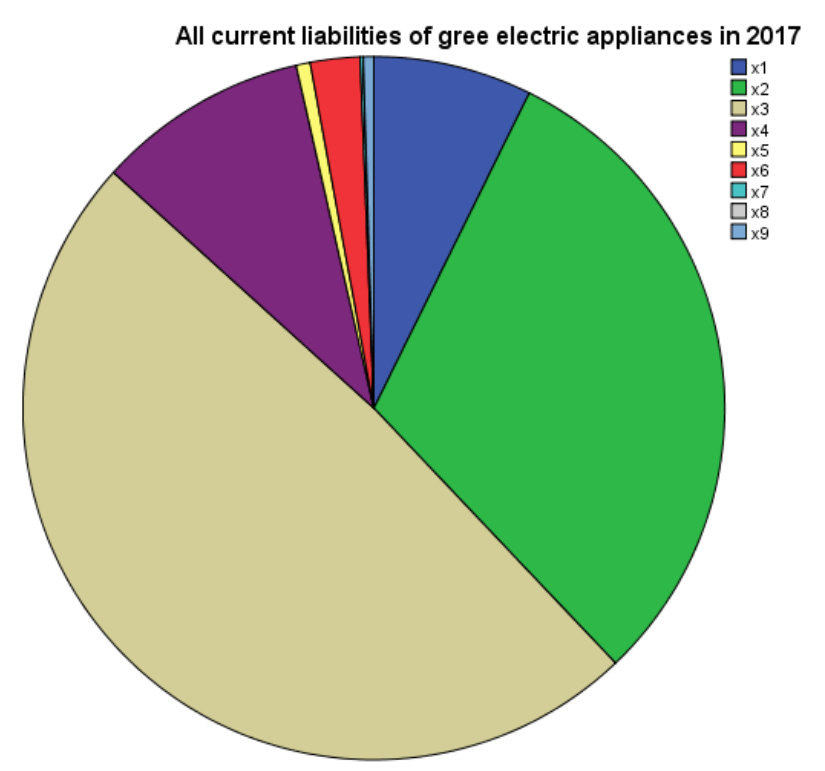

Fig 1. Current liabilities in 2017

\section{Summary}

Gere electric appliance adopts the strategy of both management and investment to maintain its core competitiveness and expand the core business of upstream and downstream by maintaining a complete production management system. And by controlling the expansion of investment to achieve the leapfrog development of the enterprise, in 2015, green has successful transformation, enterprises are no longer just an air conditioning, green electric appliances is trying to smart home, mobile phones and other appliances, and other direction to seek diversified development, eventually making green electric active and steady development. The combination of operation and investment strategy can, on the one hand, consolidate the main business scale of the enterprise, maintain a certain competitive position in the market and reduce the operating risk of core assets. On the other hand, the diversification of products and businesses can be realized through external controlling investment, expanding market and reducing enterprise risk.

\section{References}

[1]. References hang Xining. Balance sheet: from elements to strategies. Accounting research.2014 (05).

[2]. Ma junkie, hang in. Financial strategy analysis based on financial statements. Exploration of BBS. $2012(02)$.

[3]. Hang Xining. Liabilities and shareholders' equity: capital introduction strategy of enterprises. Finance and accounting. 2015 (21). 